\title{
Adjuvant and Salvage Radiotherapy for Urothelial Cell Carcinoma of the Upper Urinary Tract: Experience in A Single Institution
}

\author{
Kang-Hsing Fan ${ }^{1,4}$, MD; Yen-Chao Chen ${ }^{3}$, MD; Wei-Man Leung ${ }^{1}, \mathrm{MD}$; \\ Cheng-Keng Chuang ${ }^{2,4}$, MD, PhD; See-Tong Pang ${ }^{2,4}$, MD, PhD; Ji-Hong Hong ${ }^{1,5}$, MD, PhD
}

Background: To investigate the role of radiotherapy (RT) for upper urinary tract urothelial cell carcinoma (UTUC) after surgery.

Methods: $\quad$ Between July 1997 and February 2007, 40 patients who had undergone radical surgery and RT were selected. Twenty patients received RT as adjuvant treatment for advanced disease (PORT). The remainder received RT as salvage treatment (SART). The prescription dose of RT ranged from 32 to 66.6 Gy (median: 50 Gy). Cisplatin-based chemotherapy was given to 34 patients. The median follow-up was 61 months ( $22-93$ months).

Results: At the time of analysis, 10 patients were alive, but two of them had tumor recurrence. Twenty-four patients died from disease recurrence, two died from chemotherapy-related complications, and two from non-cancer comorbidities. Two patients were lost to follow-up but one of them had tumor recurrence. The 3-year overall survival (OS) was $45 \%$ for the PORT group, and $16 \%$ for the SART group ( $p=0.03$ ). The 3-year progression-free survival (PFS) was $41 \%$ for the PORT group, and $12 \%$ for the SART group ( $p=$ $0.02)$. A prescription dose $<50$ Gy $(p=0.02)$ was another poor prognostic factor. The 3-year OS was 38\% for a prescription dose $\geq 50 \mathrm{~Gy}$, and $18 \%$ for $<50$ Gy $(p=0.06)$. The 3 -year PFS improved from $7 \%$ to $41 \%$ if the prescribed dose was $\geq 50$ Gy $(p<0.05)$.

Conclusion: According to our analysis, RT combined with chemotherapy is effective in the postoperative treatment of advanced disease and salvage treatment for recurrent UTUC. The prescription dose should be $\geq 50 \mathrm{~Gy}$.

(Chang Gung Med J 2012;35:247-54)

Key words: upper urinary tract, urothelial cell carcinoma, postoperative, recurrence, radiotherapy

$\mathrm{U}$ rothelial cell carcinomas of the upper urinary tract (UTUC), including the ureter and renal pelvis, are uncommon malignancies. These account for 5\% of all urothelial cancers and $7 \%$ of all renal tumors in the USA. ${ }^{(1)}$ In Taiwan, UTUC is more common but still composes less than one-third of all

\footnotetext{
From the ${ }^{1}$ Department of Radiation Oncology; ${ }^{2}$ Division of Urology, Department of Surgery, Chang Gung Memorial Hospital at Linkou; ${ }^{3}$ Department of Radiation Oncology, Chang Gung Memorial Hospital at Keelung, Chang Gung University College of Medicine, Taoyuan, Taiwan; ${ }^{4}$ Graduate Institute of Clinical Medical Science; ${ }^{5}$ Department of Medical Imaging and Radiological Science, College of Medicine, Chang Gung University, Taoyuan, Taiwan.

Received: July 23, 2010; Accepted: Nov. 14, 2011

Correspondence to: Dr. Ji-Hong Hong, Department of Radiation Oncology, Chang Gung Memorial Hospital at Linkou. 5, Fusing St., Gueishan Township, Taoyuan County 333, Taiwan (R.O.C.) Tel: 886-3-3281200 ext. 2601; Fax: 886-3-3280797;

E-mail: jihong@cgmh.org.tw
} 
urinary tract cancers. ${ }^{(2)}$ Usually, patients with UTUC are treated with radical surgery, and radiotherapy (RT) has not had an established role. Local-regional control of T1 to T3 stage disease is excellent in surgical series, ${ }^{(3,4)}$ and isolated local recurrence is rare. ${ }^{(5)}$ Bladder and distant recurrences are the most common pattern of first recurrence. ${ }^{(3,6)}$ Thus, adjuvant RT does not provide much benefit for most patients in theory. Past studies that examined the benefits of adjuvant RT also have not consistently supported the usage of postoperative RT. For example, Cozad and colleagues reported significant improvement in local control, and marginal improvement in the overall survival (OS). ${ }^{(7)}$ Another report, by Maulard-Durdux et al., showed that adjuvant RT did not provide any benefit at all. ${ }^{(8)}$ Hall and colleagues also reported that adjuvant RT had no positive effect. ${ }^{(9)}$ Therefore, adjuvant RT is not a routine treatment at the present time. However, there are some questions about this conclusion. First, recurrence patterns may vary with stage. Most surgical series showed local-regional recurrence without stratification by stage or other risk factors. Actually, local-regional recurrence is similar to distant metastasis in patients with a high risk of recurrence. ${ }^{(10)}$ Many studies did not include routine computed tomography (CT) or magnetic resonance imaging (MRI) to detect asymptomatic recurrence during follow-up. ${ }^{(5)}$ Local-regional recurrence might be missed. Second, studies which had negative results used old RT techniques. The prescribed dose of RT, which was limited by normal organ tolerance, was usually suboptimal. Thus, an out-of-date RT technique would result in inadequate tumor control. ${ }^{(6,8)}$ Moreover, it may cause excess damage to healthy organs, and offset the benefits of RT.

For recurrent UTUC, chemotherapy is the most common salvage treatment. However, isolated local or regional recurrence does occur in some of our patients. Local irradiation is applied in these patients, but the effectiveness of salvage RT is unknown, because clinical results for reference are lacking.

To solve these two questions, we performed this retrospective study to analyze treatment outcomes of adjuvant and salvage RT after surgery. Furthermore, this study may provide useful information for physicians who have encountered these uncommon indications for radiotherapy.

\section{METHODS}

This study included 40 patients with UTUC who received radical surgery and RT in our hospital from July 1997 to February 2007. All patients had a good performance status and had received radical surgery as the primary treatment. Among the 40 patients, 20 had adjuvant RT for positive resection margins or advanced disease (PORT). The remainder had RT as salvage treatment (SART) for local-regional recurrence. Patients who had metastatic disease or histology other than urothelial carcinoma, or who had received short-term palliative RT were excluded from this study.

Tumor staging was pathologic staging for the PORT group and clinical staging for the SART group. It followed the American Joint Committee on Cancer staging criteria; staging results were revised according to the 2002 staging system. ${ }^{(11)}$ In addition, we recorded the status of the surgical margins, method and conditions of lymph node dissection, the degree of histologic differentiation, the site of origin, laterality, perineural invasion, and lymphatic permeation in the PORT group. The patient characteristics of each group are listed in Table 1 .

The prescription dose of RT ranged from 32 to 66.6 Gy (median: $50 \mathrm{~Gy}$ ), with 1.8 or $2 \mathrm{~Gy}$ in one fraction per day, 5 days per week. All patients were treated with 3-D conformal radiotherapy or intensitymodulated radiotherapy. For the PORT group, the clinical target volume (CTV) included the tumor bed and paraaortic nodal area. For the SART group, the CTV was an expansion of the gross tumor, which covered the microscopic extension of the tumor. The expansion from the CTV to the planning target volume (PTV) was around $1 \mathrm{~cm}$ in 3 dimensions, and modified by the physician individually. The minimal doses delivered to the CTV and PTV were $100 \%$ and $95 \%$ of the prescription dose. respectively, while the maximal dose could not exceed $110 \%$ of the prescription dose. Chemotherapy had been given to 34 patients in varied regimens and combinations with RT. Twenty-six patients had received concurrent and adjuvant cisplatin-based chemotherapy. Eight patients had received similar regimens of chemotherapy only after radiotherapy.

After RT, patients were followed regularly in the outpatient department. Image evaluation such as CT 
scans and chest radiographs were done every 6 to 12 months or when there was any sign of tumor recurrence. If tumor recurrence was detected, it was proved by biopsy or at least 2 examinations. The

Table 1. Characteristics of All Patients

\begin{tabular}{|c|c|c|}
\hline \multirow[b]{2}{*}{ Category } & \multicolumn{2}{|c|}{ Frequency } \\
\hline & $\begin{array}{l}\text { Adjuvant RT } \\
\text { (20 patients) }\end{array}$ & $\begin{array}{l}\text { Salvage RT } \\
\text { (20 patients) }\end{array}$ \\
\hline Median age & $61 \mathrm{y} / \mathrm{o}(49-79)$ & $66 \mathrm{y} / \mathrm{o}(27-82)$ \\
\hline \multicolumn{3}{|l|}{ Sex } \\
\hline Male & 9 & 10 \\
\hline Female & 11 & 10 \\
\hline \multicolumn{3}{|l|}{ Site of tumor } \\
\hline Renal pelvis & 7 & 9 \\
\hline Ureter & 9 & 5 \\
\hline Both & 4 & 6 \\
\hline T-stage & (Pathologic) & (Recurrent) \\
\hline T0 & 0 & 7 \\
\hline $\mathrm{T} 3$ & 11 & 0 \\
\hline $\mathrm{T} 4$ & 9 & 13 \\
\hline Nodal status & (Pathologic) & (Recurrent) \\
\hline Negative & 4 & 10 \\
\hline Positive & 5 & 10 \\
\hline Unknown/no dissection & 11 & 0 \\
\hline \multicolumn{3}{|l|}{ Grade } \\
\hline Low or intermediate & 3 & 2 \\
\hline High & 16 & 16 \\
\hline Not specified & 1 & 2 \\
\hline \multicolumn{3}{|l|}{ Margin status } \\
\hline Negative & 16 & NA \\
\hline Positive & 3 & \\
\hline Unknown & 1 & \\
\hline \multicolumn{3}{|l|}{ Perineural invasion } \\
\hline Negative & 17 & NA \\
\hline Positive & 3 & \\
\hline \multicolumn{3}{|l|}{ Lymphovascular invasion } \\
\hline Negative & 13 & NA \\
\hline Positive & 7 & \\
\hline \multicolumn{3}{|l|}{ Chemotherapy } \\
\hline Yes & 16 & 18 \\
\hline No & 4 & 2 \\
\hline \multicolumn{3}{|l|}{ Radiation dose } \\
\hline$<50 \mathrm{~Gy}$ & 8 & 9 \\
\hline $50 \mathrm{~Gy}$ or more & 12 & 11 \\
\hline
\end{tabular}

Abbreviations: RT: radiotherapy; NA: not applicable. type of recurrence was determined by the records of the radiologist or primary care doctor. Generally, recurrence at the retroperitoneal space around the renal fossa was defined as local recurrence. Nodal recurrence in the paraaortic region was defined as regional recurrence. If another tumor developed in the rest of urinary tract, it was recorded as a second urinary tract cancer rather than progression of the tumor. Tumor recurrence outside the above region was defined as distant metastasis. The primary endpoint was disease progression. Death was another endpoint of this study. Survival was dated from the end of RT. The median follow-up time was 20 months (1-93 months).

For incidence of event, Pearson's chi-quare test and Fisher's exact test were used to determine the significance of difference. For survival analysis, we used the Kaplan-Meier method and the log-rank test to determine the significance of differences between endpoints of different patients. The Cox regression model was used to perform multivariate analysis. The relation of each variable to the endpoints was compared with both univariate and multivariate analysis. Differences were considered significant when the $p$ value was less than 0.05 . We used the commercial statistics package SPSS 11.0 (SPSS Inc., Chicago, IL, U.S.A.).

\section{RESULTS}

At the time of analysis, 9 patients were still alive, but two of them had tumor recurrence. Twenty-five patients died from recurrent disease. Two patients (one in each group) died from chemotherapy-related complications, and two from non-cancer comorbidities. Two patients were lost to follow-up, and one of them had tumor recurrence.

The 3-year overall survival OS was $45 \%$ for the PORT group, and 16\% for the SART group ( $p=$ $0.03)$. The median OS was 29 months and 15 months $(p=0.03)$, and the 3-year progression-free survival (PFS) was $41 \%$ and $12 \%$ ( $p=0.02$ ), respectively. The median OS was 28 months and 15 months. And the median PFS was 21 months and six months, respectively.

Tumors recurred in 29 patients. Distant metastasis was the first recurrence in 17 patients, and localregional recurrence was the first recurrence in 11 patients. One patient had bladder cancer as the only 
cancer event after completion of adjuvant radiotherapy. A total of four patients developed a second urinary tract cancer during follow-up. The failure pattern was similar in the PORT and SART groups. Local -regional failure occurred as the first recurrence in three patients in the PORT group (15\%), and in six in the SART group (30\%, Fisher's exact test: $p$ $=0.273)$. Distant failure was the first tumor recurrence in nine patients in the PORT group $(45 \%)$ and eight in the SART group (40\%, chi-square test: $p=$ 0.855).

In univariate analysis, a prescription dose $<50$ Gy $(p=0.02)$, and SART ( $p=0.04)$ were significant prognostic factors for the OS (Fig. 1 and 2) and PFS. The 3-year OS increased from $18 \%$ to $38 \%$ ( $p=$ 0.06 ) if the prescription dose was $\geq 50 \mathrm{~Gy}$. The median OS increased from 15 months to 28 months, as well. The 3-year PFS with a prescription dose $\geq 50$ Gy was $41 \%$, and $7 \%$ with a prescription dose $<50$ Gy $(p<0.05)$. The median PFS was prolonged from 6 months to 21 months when the prescription dose was $\geq 50 \mathrm{~Gy}$. The detailed dose response of different groups is listed in Table 2. In multivariate analysis, SART was the only independent factor for OS $(p=0.02)$, and the prescription dose was the only independent factor for PFS ( $p=0.02)$ (Table 3).

\section{DISCUSSION}

Currently, treatment of advanced UTUC is a dif-

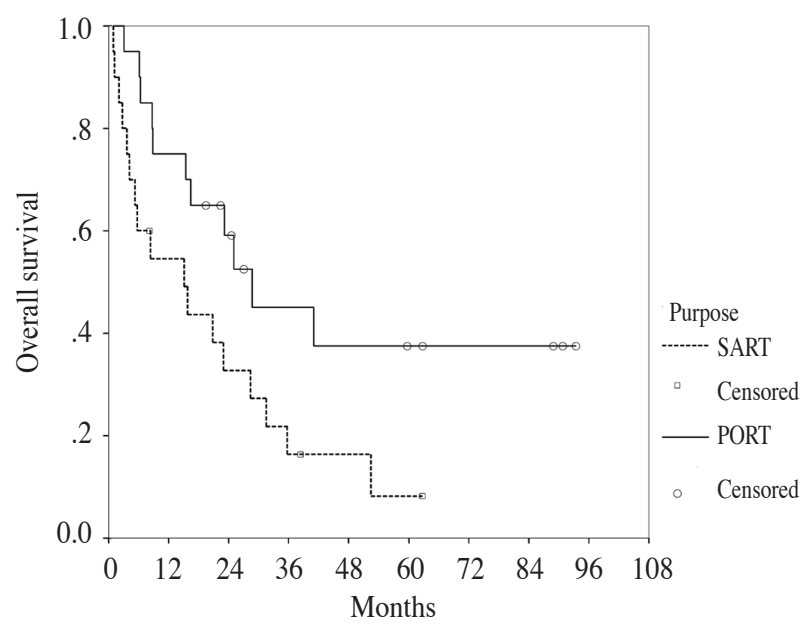

Fig. 1 Overall survival of the PORT and SART Groups (logrank test $p=0.04)$. Abbreviations used: PORT: adjuvant treatment for advanced disease; SART: salvage treatment. ficult task. The PFS and OS are both poor, and there is no solid evidence to support the role of adjuvant treatment. However, we found several intriguing issues during a review of the literature. Most studies involving radical surgery did not report the localregional recurrence rates of different stages of disease in detail. ${ }^{(3,5,6)}$ In studies which described recurrence patterns, local-regional recurrence rates were relatively higher with certain specific conditions, such as extensive parenchymal invasion or residual tumor. ${ }^{(4,12)}$ High grade tumors also correlated with a higher local recurrence rate. ${ }^{(3)}$ In addition, evaluation

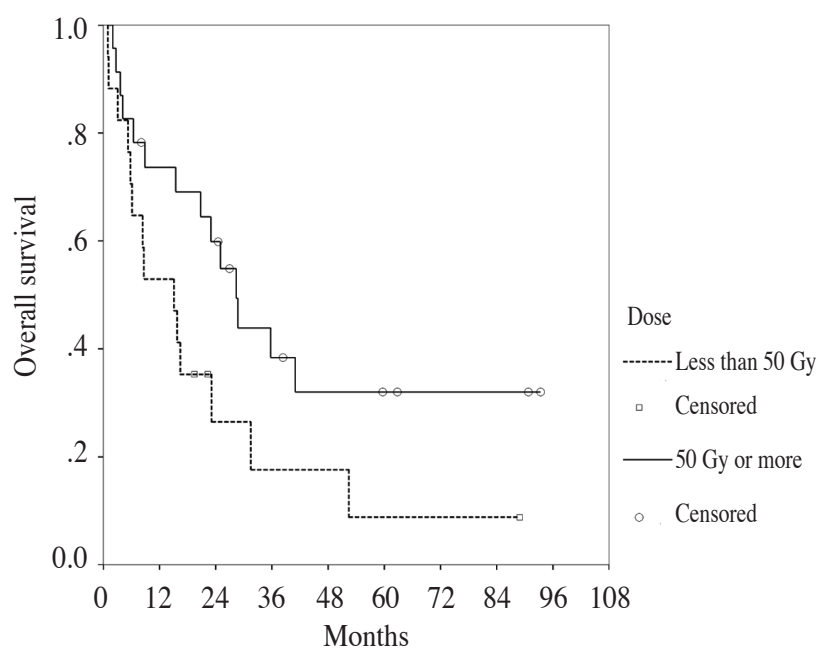

Fig. 2 Overall survival of dose prescriptions $<$ and $\geqq 50$ Gy (log-rank test $p=0.02$ ).

Table 2. Responses to Radiotherapy

\begin{tabular}{lcccc}
\hline Category & $\begin{array}{c}\text { Median } \\
\text { OS time } \\
\text { (months) }\end{array}$ & 3 year OS & $\begin{array}{c}\text { Median } \\
\text { PFS } \\
\text { time } \\
\text { (months) }\end{array}$ & $\begin{array}{c}\text { 3-year } \\
\text { progression- } \\
\text { free } \\
\text { survival }\end{array}$ \\
\hline PORT & 29 & $45 \%$ & 21 & $41 \%$ \\
$\quad<50$ Gy & 16 & $25 \%$ & 9 & $16 \%$ \\
$\quad 50$ Gy or higher & 41 & $56 \%$ & 41 & $56 \%$ \\
& & & & \\
SART & 15 & $16 \%$ & 6 & $12 \%$ \\
$<50$ Gy & 8 & 0 & 2 & 0 \\
$\quad 50$ Gy or higher & 23 & $20 \%$ & 11 & $34 \%$ \\
\hline
\end{tabular}

Abbreviations: OS: overall survival; PFS: progression-free survival; PORT: adjuvant treatment for advanced disease; SART; salvage treatment. 
Table 3. Multivariate Analysis of Different Prognostic Factors on Overall Survival and Progression Free Survival

\begin{tabular}{|c|c|c|c|c|}
\hline \multirow[b]{2}{*}{ Category (reference) } & \multicolumn{2}{|c|}{ Overall survival } & \multicolumn{2}{|c|}{ Progression-free survival } \\
\hline & $\begin{array}{c}\text { Hazard ratio } \\
(95 \% \text { confidence interval) }\end{array}$ & $p$ - value & $\begin{array}{c}\text { Hazard ratio } \\
\text { (95\% confidence interval) }\end{array}$ & $p$ - value \\
\hline Age (continous) & $0.99(0.95-1.02)$ & 0.45 & $0.98(0.93-1.03)$ & 0.32 \\
\hline Sex (male) & $0.82(0.33-2.02)$ & 0.67 & $0.52(0.2-1.37)$ & 0.19 \\
\hline \multicolumn{5}{|l|}{ Stage (recurrent T4) } \\
\hline Recurrent T0 & $0.92(0.26-3.23)$ & 0.89 & $2.53(0.31-21)$ & 0.89 \\
\hline Pathological T4 & $0.62(0.15-2.53)$ & 0.5 & $1.03(0.113-9.371)$ & 0.39 \\
\hline Pathological T3 & $0.194(0.04-1.06)$ & 0.06 & $0.36(0.11-1.16)$ & 0.09 \\
\hline Grade (low grade) & $1.08(0.69-1.67)$ & 0.95 & $0.86(0.37-2)$ & 0.72 \\
\hline Group (PORT) & $2.67(1.14-6.24)$ & 0.02 & $2.34(0.97-5.13)$ & 0.06 \\
\hline Perineural invasion (no) & $3.70(0.95-14.47)$ & 0.06 & $2.59(0.4-16.69)$ & 0.32 \\
\hline Lymphovascular invasion (no) & $0.95(0.18-5.03)$ & 0.82 & $2.42(0.78-7.48)$ & 0.13 \\
\hline Chemotherapy (yes) & $0.99(0.28-3.56)$ & 0.91 & $1.11(0.31-3.98)$ & 0.87 \\
\hline Radiation Dose ( $\geq 50$ Gy) & $1.96(0.92-4.19)$ & 0.08 & $2.52(1.16-5.51)$ & 0.02 \\
\hline
\end{tabular}

Abbreviation: PORT: adjuvant treatment for advanced disease.

with CT or MRI during follow-up was usually elective or not mentioned..$^{(5,6,13)}$ Isolated local-regional relapses might be missed without regular image examination. $\mathrm{Li}$ and colleagues reported local recurrence rates of $31 \%$ and $12 \%$ for pathologic $\mathrm{T} 4$ and T3 disease with abdominal CT scan applied during follow-up. With specification of risk factors and routine evaluation of modern image examinations, it is possible to identify a group of patients with a significantly higher local-regional recurrence rate. Adjuvant RT may provide benefits for them.

Although it is rare and the evidence strength is poor, there is some evidence supporting the role of adjuvant RT. ${ }^{(7,12)}$ Studies that did not support adjuvant radiotherapy used old RT techniques, and thus, the benefits of adjuvant RT could be offset by complications. ${ }^{(6,8)}$ In addition, the median prescription dose, which was 45 Gy in one study and 39.8 Gy in another, was relatively low. Technical and dose issues might be the reasons why adjuvant RT was ineffective in those studies. One retrospective study showed good clinical outcomes after postoperative RT with a median dose of $46.9 \mathrm{~Gy}$. The five-year actuarial OS was $39 \% .{ }^{(14)}$ Our study showed similar results, with a 3 -year OS of 46\%, comparable with the outcome of advanced disease in a surgery series. ${ }^{(5)}$ The localrecurrence rate of the PORT group was $15 \%$ in our study, which is better than in some surgical series which described local-regional recurrence in results. ${ }^{\left({ }^{3}, 1,2\right)}$ Thus, postoperative RT should be effective in patients with a high risk of local recurrence, such as residual, pathologic $\mathrm{T} 4$, or high grade tumors.

Salvage treatment for local-regional recurrence is another tough problem. For metastatic urothelial carcinoma, a cisplatin-based combination regimen has a median survival of up to 16 months. ${ }^{(15-17)}$ Second-line chemotherapy with a variable regimen has a median PFS of approximately 4 months, and an OS of up to 9 months; ${ }^{(18-20)}$ however, reports of salvage treatment for isolated local-regional recurrence are rare. Local- regional recurrence causes severe pain that is difficult to relieve by medication or chemotherapy. Local irradiation is another choice to relieve symptoms and prolong PFS. Our study showed a median PFS of 6 months in the SART group. Two of 10 patients who received a dose $\geq 50$ Gy remained progression-free after 3 years. Therefore, local irradiation with a dose of more than 50 Gy should be considered when isolated local- 
regional recurrence is found.

Out study suggests a radiation dose response; both the OS and PFS were increased with a higher dose. Formerly, the radiation dose was usually limited to $45 \mathrm{~Gy}$ or less to prevent severe damage to abdominal organs. With the invention of new radiotherapy techniques, delivering a radiation dose more than $50 \mathrm{~Gy}$ is now possible. Several studies have reported clinical experience with radiotherapy with a prescription dose $>50$ Gy in the abdominal region. The toxicity was tolerable, for both cancer in the abdominal region and para-arotic nodal metastasis. ${ }^{(21-}$ ${ }^{23)}$ So, if patients are to receive RT for UTUC, a prescription dose $\geq 50$ Gy with a novel RT technique is recommended. This modality can effectively delay disease progression and prolong OS.

In conclusion, our study represents a series of adjuvant and salvage RT for UTUC. For adjuvant treatment, RT reduced disease recurrence with a higher prescription dose. For salvage treatment of local-regional recurrence, long-term survival is possible. It seems that RT combined with chemotherapy is effective for adjuvant or salvage treatment for advanced and recurrent UTUC. According to our analysis, the prescription dose should be $\geq 50$ Gy for both adjuvant and salvage RT. Although long-term survival can be achieved, the overall treatment result is poor. Investigation of novel effective treatments is needed.

\section{Acknowledgements}

The authors would like to thank all members of Linkou Chang Gung Genitourinary Oncology Group and Radiation Oncology Department of Linkou Chang Gung Memorial Hospital for their invaluable help in the preparation of this analysis.

\section{REFERENCES}

1. Reitelman C, Sawczuk IS, Olsson CA, Puchner PJ, Benson MC. Prognostic variables in patients with transitional cell carcinoma of the renal pelvis and proximal ureter. J Urol 1987;138:1144-5.

2. Taiwan Cancer Registry (Chinese), 2007. Available from http://www.bhp.doh.gov.tw/BHPnet/Portal/StatisticsShow. aspx?No=201105200001. Accessed May, 2011.

3. Li CC, Chang TH, Wu WJ, Ke HL, Huang SP, Tsai PC, Chang SJ, Shen JT, Chou YH, Huang CH. Significant predictive factors for prognosis of primary upper urinary tract cancer after radical nephroureterectomy in
Taiwanese patients. Eur Urol 2008;54:1127-34.

4. Wu CF, Pang ST, Chen CS, Chuang CK, Chen Y, Lin PY. The impact factors on prognosis of patients with pT3 upper urinary tract transitional cell carcinoma. J Urol 2007;178:446-50, dicussion 50.

5. Margulis V, Shariat SF, Matin SF, Kamat AM, Zigeuner R, Kikuchi E, Lotan Y, Weizer A, Raman JD, Wood CG. Outcomes of radical nephroureterectomy: a series from the Upper Tract Urothelial Carcinoma Collaboration. Cancer 2009;115:1224-33.

6. Hall MC, Womack S, Sagalowsky AI, Carmody T, Erickstad MD, Roehrborn CG. Prognostic factors, recurrence, and survival in transitional cell carcinoma of the upper urinary tract: a 30-year experience in 252 patients. Urology 1998;52:594-601.

7. Cozad SC, Smalley SR, Austenfeld M, Noble M, Jennings $\mathrm{S}$, Reymond R. Adjuvant radiotherapy in high stage transitional cell carcinoma of the renal pelvis and ureter. Int $\mathbf{J}$ Radiat Oncol Biol Phys 1992;24:743-5.

8. Maulard-Durdux C, Dufour B, Hennequin C, Chretien Y, Vignes B, Droz D, Delanian S, Housset M. Postoperative radiation therapy in 26 patients with invasive transitional cell carcinoma of the upper urinary tract: no impact on survival? J Urol 1996;155:115-7.

9. Hall MC, Womack JS, Roehrborn CG, Carmody T, Sagalowsky AI. Advanced transitional cell carcinoma of the upper urinary tract: patterns of failure, survival and impact of postoperative adjuvant radiotherapy. J Urol 1998;160:703-6.

10. Kim DS, Lee YH, Cho KS, Cho NH, Chung BH, Hong SJ. Lymphovascular invasion and pT stage are prognostic factors in patients treated with radical nephroureterectomy for localized upper urinary tract transitional cell carcinoma. Urology 2010;75:328-32.

11. Frederick L, Greene DLP, Fleming ID, Fritz A, Balch CM, Haller DG, Morrow M. AJCC Cancer Staging Manual. 6th ed. Springer-Verlag, 2002.

12. Ozsahin M, Zouhair A, Villa S, Storme G, Chauvet B, Taussky D, Gouders D, Ries G, Bontemps P, Coucke PA, Mirimanoff RO. Prognostic factors in urothelial renal pelvis and ureter tumours: a multicentre Rare Cancer Network study. Eur J Cancer 1999;35:738-43.

13. Lughezzani G, Jeldres C, Isbarn H, Sun M, Shariat SF, Alasker A, Pharand D, Widmer H, Arjane P, Graefen M, Montorsi F, Perrotte P, Karakiewicz PI. Nephroureterectomy and segmental ureterectomy in the treatment of invasive upper tract urothelial carcinoma: a populationbased study of 2299 patients. Eur J Cancer 2009;45:32917.

14. Czito B, Zietman A, Kaufman D, Skowronski U, Shipley W. Adjuvant radiotherapy with and without concurrent chemotherapy for locally advanced transitional cell carcinoma of the renal pelvis and ureter. J Urol 2004;172: 1271-5.

15. Sternberg CN, Yagoda A, Scher HI, Watson RC, Geller N, 
Herr HW, Morse MJ, Sogani PC, Vaughan ED, Bander N, Weiselberg L, Rosado K, Smart T, Lin SY, Penenberg D, Fair WR, Whitmore WF Jr. Methotrexate, vinblastine, doxorubicin, and cisplatin for advanced transitional cell carcinoma of the urothelium. Efficacy and patterns of response and relapse. Cancer 1989;64:2448-58.

16. Logothetis CJ, Dexeus FH, Finn L, Sella A, Amato RJ, Ayala AG, Kilbourn RG. A prospective randomized trial comparing MVAC and CISCA chemotherapy for patients with metastatic urothelial tumors. J Clin Oncol 1990;8:1050-5.

17. Loehrer PJ Sr, Einhorn LH, Elson PJ, Crawford ED, Kuebler P, Tannock I, Raghavan D, Stuart-Harris R, Sarosdy MF, Lowe BA. A randomized comparison of cisplatin alone or in combination with methotrexate, vinblastine, and doxorubicin in patients with metastatic urothelial carcinoma: a cooperative group study. J Clin Oncol 1992;10:1066-73.

18. Krege S, Rembrink V, Borgermann C, Otto T, Rubben H. Docetaxel and ifosfamide as second line treatment for patients with advanced or metastatic urothelial cancer after failure of platinum chemotherapy: a phase 2 study. $\mathrm{J}$ Urol 2001;165:67-71.

19. Bellmunt J, Theodore C, Demkov T, Komyakov B, Sengelov L, Daugaard G, Caty A, Carles J, JagielloGruszfeld A, Karyakin O, Delgado FM, Hurteloup P,
Winquist E, Morsli N, Salhi Y, Culine S, von der Maase $\mathrm{H}$. Phase III trial of vinflunine plus best supportive care compared with best supportive care alone after a platinum-containing regimen in patients with advanced transitional cell carcinoma of the urothelial tract. J Clin Oncol 2009;27:4454-61.

20. Sweeney CJ, Roth BJ, Kabbinavar FF, Vaughn DJ, Arning M, Curiel RE, Obasaju CK, Wang Y, Nicol SJ, Kaufman DS. Phase II study of pemetrexed for second-line treatment of transitional cell cancer of the urothelium. J Clin Oncol 2006;24:3451-7.

21. Aoki T, Nagata Y, Mizowaki T, Kokubo M, Negoro Y, Takayama K, Mitsumori M, Sasai K, Hiraoka M. Clinical evaluation of dynamic arc conformal radiotherapy for paraaortic lymph node metastasis. Radiother Oncol 2003;67:113-8.

22. Hodges JC, Das P, Eng C, Reish AG, Beddar AS, Delclos $\mathrm{ME}$, Krishnan S, Crane $\mathrm{CH}$. Intensity-modulated radiation therapy for the treatment of squamous cell anal cancer with para-aortic nodal involvement. Int J Radiat Oncol Biol Phys 2009;75:791-4.

23. Yovino S, Poppe M, Jabbour S, David V, Garofalo M, Pandya N, Alexander R, Hanna N, Regine WF. Intensitymodulated radiation therapy significantly improves acute gastrointestinal toxicity in pancreatic and ampullary cancers. Int J Radiat Oncol Biol Phys 2011;79:158-62. 


\title{
輔助性及救援性放射治療應用於上泌尿道泌尿上皮癌： 單一機構治療經驗
}

\author{
范網行 ${ }^{1,4}$ 陳彦超 ${ }^{3}$ 梁爲民1 莊正鏗,4 馮思中2,4 洪志宏 ${ }^{1,5}$
}

背 景：探討本院於輔助性及救援性放射治療應用於上泌尿道泌尿上皮癌的治療經驗。

方 法：在 1997 年 7 月到 2007 年 2 月間, 有 40 位病患罹患上泌尿道的泌尿上皮癌, 於手術 後接受放射線治療。其中有 20 名病患因晚期癌症接受輔助放射治療, 而另外 20 名 病患則是發生復發後接受救援放射治療。放射治療劑量介於 32 到 66.6 格雷 (中位 數: 50 格雷)。共有 34 名病患接受以順鉑爲基礎的化學治療。追蹤期的中位數爲 61 個月（範圍：22-93個月）。

結 果：目前仍有 10 名病患存活, 但其中兩名帶有復發腫瘤。2 4 名病患已死於腫瘤惡化, 2 名病患死於化療相關副作用, 以及兩名病患死於其他疾病。有一名病患在確認腫瘤 復發後失去聯絡。三年的存活率, 輔助放射治療組爲 $45 \%$ 輔助放射治療組爲 $16 \%(p$ $=0.03) \circ 三$ 年無腫瘤檼化存活率, 輔助放射治療組爲 $41 \%$ 輔助放射治療組爲 $12 \%(p$ $=0.02)$ 。放射治療劑量小於 $50 \mathrm{~Gy}$ 爲另一預後不良因子。三年的存活率, 劑量 50 格 雷以上的病患爲 $38 \%$, 劑量小於 50 格雷爲 $18 \%(p=0.06)$ 。三年無腫瘤惡化存活率可 由 $7 \%$ 提升至 $41 \%(p<0.05)$, 若放射治療劑量提高到 50 格雷以上。

結 論: 根據本研究分析, 輔助性及救援性放射治療對晚期或復發的上泌尿道的泌尿上皮癌 是一有效的治療，但放射治療劑量應給予至 50 格雷以上。

(長庚醫誌 2012;35:247-54)

關鍵詞：上泌尿道，泌尿上皮癌，手術後，復發，放射治療

長庚醫療財團法人林口長庚紀念醫院 1 1放射腫瘤科, 2 泌尿科; 3 長庚醫療財團法人基隆長庚紀念醫院 放射腫瘤科; 長庚大 學 醫學院 4臨床醫學研究所, 醫學影像紀放射科學系。

受文日期 : 民國99年7月23日 ; 接受刊載 : 民國100年11月14日

通訊作者: 洪志宏醫師, 長庚醫療財團法人林口長庚紀念醫院 放射腫瘤科。桃園縣333龜山嚮復興街5號。

Tel: (03)3281200轉2601; Fax: (03)3280797; E-mail: jihong@ cgmh.org.tw 